Reynir Arngrímsson, MD, PhD

Chairman of the Executive Board of the Medical Council

Professor of Clinical Genetics/Genetic Medicine, University of Iceland

Dept. Genetics and Molecular Medicine

Landspítali University Hospital, 101 Reykjavík

https://doi.org/10.17992/lbl.2017.0708.143

\section{Reynir Arngrímsson}

prófessor í klínískri erfðafræði/ erfðalæknisfræði, Háskóla Íslands. formaður læknaráđs Landspítala

formaður Læknafélags Íslands frá okt. 2017

reynirar@landspitali,is

\title{
Miklar kröfur gerðar til lækna
}

Vorið 2017 hefur verið viðburðaríkur tími í sögu Læknafélags Íslands. Nú síðast er undirritun nýs kjarasamnings sem félagsmenn hafa sampykkt. Eitt helsta verkefni LÍ er og verður að gæta hagsmuna félagsmanna sinna. Til lækna eru gerðar miklar kröfur og meiri en til annarra stétta heilbrigðiskerfisins. Á pessu er meðal annars tekið í málflutningi fyrir kærunefnd jafnréttismála sem felldi úrskurð sinn pann 18. maí 2017 í máli Félags íslenskra hjúkrunarfræðinga gegn Landspítala. ${ }^{1}$ Par kemur fram að pó staða hjúkrunardeildarstjóra og yfirlæknis sé sú sama í skipuriti, séu pau í meginatriðum ekki samanburðarhæf. Pannig sé grunnkrafa í starfi hjúkrunardeildarstjóra hjúkrunarleyfi en að baki pví sé fjögurra ára háskólanám. Að baki sérfræðiviðurkenningu læknis er hins vegar að lágmarki 11-14 ára nám, 6 ár í háskóla, eins árs kandídatsár og fjögurra til 7 ára viðbótarnám erlendis. Pá er bent á að í lögum sé gerður greinarmunur á ráðningarferli í pessi störf. Samkvæmt 35. gr. laga nr. 40/2007 skuli bera umsóknir um yfirlæknisstörf undir sérstaka nefnd sem skipuð sé af heilbrigðisráðherra, pað er stöðunefnd lækna. Sambærilegar kröfur eru ekki gerðar í lögum varðandi umsækjendur um störf hjúkrunardeildarstjóra. Löggjafinn gerir pví að pessu leyti strangari kröfur til umsækjenda um yfirlæknisstöður. Í starfslýsingu yfirlækna er líka sérstaklega tilgreint að peim beri að sinna klínískri vinnu samhliða stjórnun og akademískri vinnu. Sambærilega skyldu er ekki að finna í starfslýsingu hjúkrunardeildarstjóra. Parna skilur verulega á milli pessara tveggja hópa stjórnenda. Pá má einnig benda á að á Landspítala eru jafnframt gerðar strangari kröfur um ráðningarferli sérfræðilækna en hjúkrunarfræðinga. Sérstök stöðunefnd læknaráðs veitir umsögn um alla umsækjendur um fastar læknastöður en slíks er ekki krafist við ráđningar hjúkrunarfræðinga. Pá er mikilvægt að hafa í huga að læknar, sérstaklega yfirlæknar, bera verulega ábyrgð í stefnumótun heilbrigðiskerfisins. petta endurspeglast meðal annars í kostnaðaráhrifum ákvarðana um dýra og læknisfræðilega meðferð og lyfjagjöf og peim er ætlað að vera leiðandi í uppbyggingu pjónustu sinnar sérgreinar. Loks má nefna kröfur sem eru ípyngjandi hvað varðar starfslok pegar ákveðnum aldri er nád. Starfsævi lækna er pví stutt miðað við flestar aðrar starfsstéttir sem meðal annars ræðst af kröfum sem settar eru fram í lögum um nám og færni í starfi. Рað er pví eðlilegt að fylgja fast eftir kröfum um eðlilega launasetningu til samræmis við pessar staðreyndir og að pað endurspeglist í kjarasamningum. Pá er mikilvægt að tekið sé tillit til stuttrar starfsævi í framlögum launagreiðanda til lífeyris og uppsöfnuð réttindi við starfslok. Nú eru að ganga í garð breytingar á reglum um lífeyrisréttindi opinberra starfsmanna og pó pau hafi ekki bein áhrif á lækna er rétt að fylgjast með peirri próun. Læknar purfa að vera virkir í að gæta hagsmuna sinna í lífeyrissjóði og gæta pess hvernig farið er með ævisparnaðinn.

Margt kallar nú á endurskoðun á skipulagi og teymisvinnu innan heilbrigðiskerfisins. Teymisvinna má ekki leiða til pess að ábyrgðarsvið lækna verði óljóst, né að öryggi sjúklingsins eða gæðum pjónustunnar sé stefnt í hættu. Fagleg læknisfræðileg ábyrgð má ekki færast úr höndum lækna, svo sem varðandi lyfjaávísanir, meðferðarákvarðanir eða stjórnun á læknisfræðilegum rannsóknarstofum.

Framundan í starfi LÍ eru mörg krefjandi og áhugaverð verkefni. Á næsta ári fögnum við 100 árum í sögu félagsins. Afmælishátíðin er í undirbúningi og hefst með Læknadögum í janúar og árshátíð. Á afmælisárinu purfum við að sýna hversu sterka liðsheild læknar mynda og fagna pessum áfanga sameiginlega. Pegar ný stjórn LÎ tekur við að afloknum næsta aðalfundi má búast við að við horfum á breytt landslag í skipulagi læknasamtakanna. Undirbúningur að peim breytingum er í höndum núverandi stjórnar Lí. Á aðalfundinum í haust er markmiðið að fyrir liggi tillögur um framtíðarskipulag í félagsmálum okkar. Mikilvægt er að sem flestir læknar taki pátt í peim undirbúningi og umræðum og myndi sér skoðun á tillögunum. Við skulum stefna að sem víðtækastri samstöðu um uppbyggingu og skipulag félags okkar.

1. Úrskurður kærunefndar jafnréttismála. Félag íslenskra hjúkrunarfræðinga gegn Landspítala. Mál nr. 6/2016. urskurdir.is/felagsmala/kaerunefndjafnrettismala/mal-nr-6-2016-1 - júní 2017. 